\title{
Implementation of Project-Based Learning Model with Edmodo Application in the Capita Selecta Chemistry Course
}

\section{Dewi Handayani, ${ }^{1}$, Endang Widi Winarni ${ }^{2}$, Agus Sundaryono ${ }^{3}$ dan M. Lutfi Firdaus ${ }^{4}$}

${ }^{1}$ Chemistry Education Study Program, University of Bengkulu, Bengkulu, Indonesia

2Department of Elementary Education, Education Faculty, University of Bengkulu, Bengkulu, Indonesia 3,4Program Pasca Sarjana S2 IPA University of Bengkulu, Bengkulu

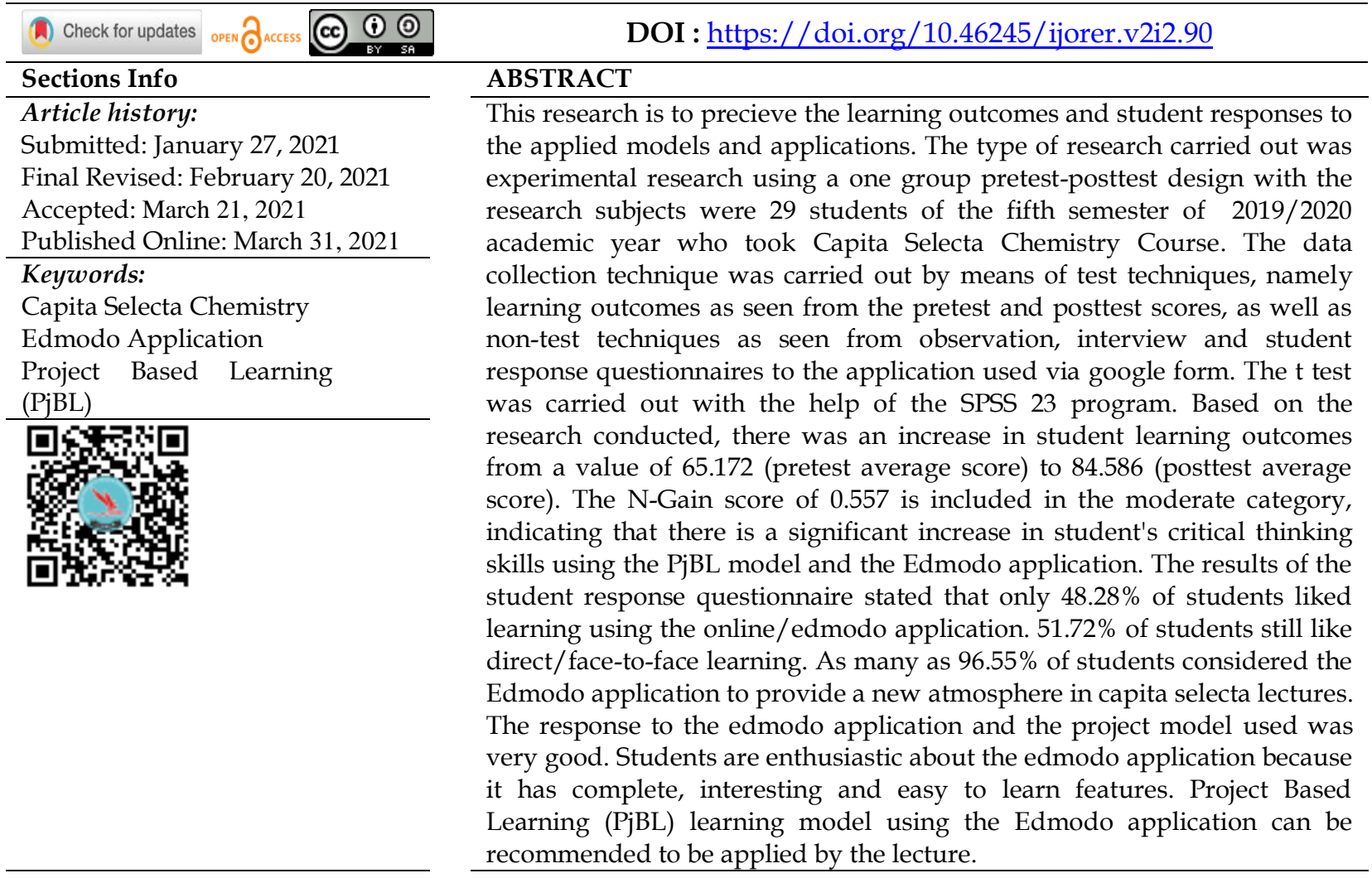

\section{INTRODUCTION}

Capita selecta in chemistry is a compulsory subject that must be taken by Chemistry Education students of Bengkulu University. This course as musch as 2 credits, with the aim of discussing specific topics in the study of Chemistry and Chemistry Education based on the latest scientific developments, in order to increase student's scientific insight. Some of the educational topics discussed include 21st century learning; Science, Technology, Engineering and Mathematics (STEM); High Orders Thingking Skils (HOTS); Learning models; Electronic-based learning media. The 21st century education paradigm requires students to have academic skills, literacy and communication skills, critical and creative thinking (Jang, H. 2016).

Based on observations of lecturers and students in the previous year. Capita selecta lectures are conducted using lectures, group discussions and assignments to students. The specific learning models and applications have not been tried in lectures. The model applied in this research is the Project Based Learning (PjBL) model. PjBL is a learning model that requires students to produce a real product (Rahman, MK, et al. 2019). In this PjBL model the role of the lecturer as a facilitator directs students to daily 
Implementation of Project-Based Learning Model with Edmodo Application in the Capita Selecta Chemistry Course

problems that are solved in groups. Lecturers provide opportunities for students to find /raise problem topics. The lecturer directs the problems that exist in the field of chemistry and chemistry education related to the latest and most recent research. Projects resulting from the PjBL model can enable students to, (1) solve real problems or current issues; (2) students can be actively involved in their learning activities and are able to find things that are considered important in the project they are undertaking; (3) students are able to show that they have mastered concepts and skills. The results of project work prove that students are able to work and learn independently. With the application of the PjBL learning model, it is hoped that the quality of learning that achieved in the curriculum can be achieved.

The PjBL model is based on previous research and the results are effective when compared to conventional methods. The results of research by Mergendoller, Maxwell, and Bellisimo (2006) and Almes Gangga (2013) indicate that PjBL improves student's macroeconomic competence compared to traditional methods. Furthermore, the results showed that the verbal ability, motivation and learning outcomes of PjBL class students were higher than those in lecture or discussion classes. Other research results indicate positive changes in attitudes and higher levels of performance in design skills among PjBL students (Mioduser \& Betzer, 2008). PjBL is also considered to be able to develop student's cognitive, affective and psychomotor (Safitri, et al., 2020; Umi, U., 2015). Alacapinar (2008) used both qualitative and quantitative analyzes including semistructured video-recorded interviews to study PjBL students versus control group students. The results showed that the PjBL students had higher cognitive abilities than the control class.

The evaluation questions used in this study use the criteria for student's critical thinking skills. Critical thinking is a technique in making rational decisions (Purwati et al., 2016). Problem-based learning models are able to improve students' critical thinking skill, to make students more actively in the class (Devy Alvionita et al., 2020). The criteria seen are focus, reason, inference, situation, clarity, overview. Critical thinking is the goal of the contemporary curriculum, where students are able to make wise decisions, are able to make, implement, analyze, synthesize and evaluate concepts and information that have been collected through the process of observation, experience, reflection and communication (Facione, 2011; Scriven \& Paul, 1996).

In implementation, the PjBL model also supports the edmodo application. The edmodo application is used with the consideration that the features presented are simple, easy for students to understand and the features in the application are also complete. There is a library feature for storing course material, assignment features, quizzes, and discussion forums. Almost all social media users have a Facebook account. This edmodo application looks similar to Facebook. Most students also think that they do not have technical problems in doing the exercises and assignments on Edmodo (Handayani, et al. 2019).

Edmodo is a school environment-based social network. Platforms are often described as facebook for schools and function to share ideas, files, agenda of activities and assignments (Prasetiyono, S \& Sondang, M., 2014; Putranti, N, 2013; Yesi Syofiarni, 2014). Edmodo can be used as a place for lecturers and students to discuss and share lecture materials in digital form and help in the learning process from a distance without having to meet face to face. Subject materials that can be posted by lecturers in 
Implementation of Project-Based Learning Model with Edmodo Application in the Capita Selecta Chemistry Course

edmodo include videos, ebooks, pictures, documents, presentations, and blogs. The advantage of Edmodo compared to other learning applications is that parents can find out and monitor the progress of their children's activities (Zakaria, 2020). In a pandemic era and online learning like this time, the use of the edmodo application in learning is helpful for controlling student's learning activities.

\section{Research Aim}

The team of authors wanted to know how the role of using the Edmodo applicationbased Project Based Learning (PjBL) learning model on learning outcomes and student responses to the learning applications used.

\section{RESEARCH METHOD}

The type of this research is an experimental research, using One Group Pretest-Posttest Design, namely using one class by first being given a preliminary test before doing the experiment. (Ihsan, et al. 2019; Ghufroni, et al. 2020). This research does not use a random sample to determine the changes caused by the treatment (Sugiyono, 2010). The research subjects consisted of 29 students in the fifth semester of the 2019/2020 academic year who took capita selecta chemistry courses.

\section{Instrument and Procedure}

The application of the PjBL model is carried out for half a semester ( 8 meetings) and it is limited to the latest issues regarding the latest educational research. Students are divided into 7 groups with different topics for each group. One group consists of 4-5 students.

The data collection technique was carried out by using test techniques, where learning outcomes seen from the pretest and posttest scores, as well as non-test techniques seen from observations, interviews and student response questionnaires to the Edmodo application which was distributed via google form. The data collected in this study were analyzed with the reliability and validity test. The test instrument used in this study refers to the indicator of critical thinking skills. The critical thinking ability test instrument was developed in the form of description questions with the criteria of focus, reason, inference, situation, clarity, overview (Table 1).

Table 1. Critical thinking ability test instrument.

\begin{tabular}{ll}
\hline \multicolumn{1}{c}{ Criteria } & \multicolumn{1}{c}{ Indicator } \\
\hline Focus & $\begin{array}{l}\text { Students can understand problems related to course material about } \\
\text { the latest developments in educational science }\end{array}$ \\
\hline Reason & $\begin{array}{l}\text { Students can argue and be able to relate problems to facts in } \\
\text { solving problems }\end{array}$ \\
\hline Inference & $\begin{array}{l}\text { Students are able to make decisions and make conclusions based on } \\
\text { existing evidence }\end{array}$ \\
\hline Situation & Students are able to find, collect and answer all problems that arise \\
\hline Clarity & $\begin{array}{l}\text { Students can provide examples of issues related to current } \\
\text { education developments, be able to make and decide the final } \\
\text { result in the form of a report }\end{array}$ \\
\hline Overview & $\begin{array}{l}\text { Students review all problems, look for sources / references until } \\
\text { the final report from beginning to end. }\end{array}$ \\
\hline
\end{tabular}


Implementation of Project-Based Learning Model with Edmodo Application in the Capita Selecta Chemistry Course

\section{Data Analysis}

The average value of student learning outcomes, calculated by :

$$
\bar{x}=\frac{\Sigma x}{n}
$$

Information:

$\bar{x} \quad:$ Mean

$\sum \mathrm{x} \quad$ : Sum Score of Students

$\mathrm{n} \quad$ : The number of students who have score (Arikunto, 2013)

Data analysis was performed using independent sample t-test. which is done with the SPSS 23.0. The test is carried out at a significant level of $5 \%$, meaning that to determine the $t$-Table statistical value, the significant level is used $\alpha=0.05$ with degrees of freedom $\mathrm{dk}=(\mathrm{nk}-1)$, with the testing criteria accepted Ho If $\mathrm{t}<\mathrm{t}$ Table, and accepted Ha if $\mathrm{t}$ count $\geq \mathrm{t}$ Table. $\mathrm{N}$-gain calculated using a formula :

Normalized Gain $(\mathrm{N}$-gain $)=$ Postest score-Pretest score

Maximal score- Pretest score (Hake, 1999)

Table 2. N-gain criteria.

\begin{tabular}{cc}
\hline Interval & Interprestasi \\
\hline $\mathrm{g} \geq 0,7$ & High \\
\hline $0,3 \leq \mathrm{g}<0,7$ & Moderate \\
\hline $\mathrm{g}<0,3$ & Low \\
\hline
\end{tabular}

The normality test is used to determine the normality of data distribution using the Kolmogrov Smirnov test with the IBM SPSS statistics 23 application. Data is declared to be normally distributed if the significance value $>0.05$ (Kadir, 2016). Analysis of the effectiveness of the PjBL learning model with the Edmodo application on student learning outcomes is calculated using the N-Gain score. Student response questionnaires to the models and applications used by looking at the percentage of student positive responses to the questionnaire given.

\section{RESULTS AND DISCUSSION}

The research was conducted on students in Semester V who took the Capita Selecta Chemistry course. As for the number of students who took is 29 people, consisting of 5 students who were male, and 24 students who were female. Students in the learning process are given project assignments using the Project Based Learning (PjBL) model. The learning activities carried out can be seen in Figure 1.

In its implementation, this PjBL model is supported by the Edmodo application. Student learning outcomes are based on the criteria for the level of critical thinking skills, i.e:

Tabel 3. Average Pretest Score, Postest Score, Gain and N-Gain

\begin{tabular}{lllllc}
\hline & \multicolumn{4}{c}{ Average Value } & Significant \\
\cline { 1 - 5 } Criteria & Pretest & Posttest & Gain & N-gain & \\
\hline Focus & 69,23 & 88,62 & 19,39 & 0,630 & Sig. (2-tailed)= \\
\cline { 1 - 5 } Reason & 63,22 & 84,70 & 21,48 & 0,584 & 0,000 \\
\hline
\end{tabular}


Implementation of Project-Based Learning Model with Edmodo Application in the Capita Selecta Chemistry Course

\begin{tabular}{|c|c|c|c|c|c|}
\hline & \multicolumn{4}{|c|}{ Average Value } & \multirow[t]{2}{*}{ Significant } \\
\hline Criteria & Pretest & Posttest & Gain & $\mathrm{N}$-gain & \\
\hline Inference & 68,23 & 87.90 & 19,67 & 0,619 & $0,000<0,05$ \\
\hline Situation & 67,61 & 83,87 & 16,26 & 0,502 & Real different \\
\hline Clarity & 68,20 & 81,88 & 13,68 & 0,430 & \\
\hline Overview & 54,54 & 80,55 & 26,01 & 0,572 & \\
\hline Total & 391,03 & 507,52 & & & \\
\hline Overall average & 65,172 & 84,586 & 19,414 & $\begin{array}{l}\text { 0,557 (Moderate } \\
\text { Category) }\end{array}$ & \\
\hline
\end{tabular}

From Table 3 it can be observed that the results of the pretest mean score of students is 65.172 and the average posttest score is 84.586 , these results indicate an increase in student learning outcomes after the implementation of the PjBL model assisted by the Edmodo application. The sig (2-tailed) value is 0,000, which means less than 0.05. So it can be concluded that there is a significant difference between the pretest and posttest scores (after being given treatment). Then determine the N-Gain score based on the results of the pretest and posttest. Analysis using N-Gain was carried out to determine the effectiveness of the PjBL and Edmodo learning models on student learning outcomes. N-Gain shows the differences in student's mastery of concepts before and after being given treatment (Amrullah, et al. 2017). Based on the results of the pretest and posttest, the N-Gain score was obtained at 0.557 . The N-Gain score is in the moderate category, indicating that the application of the PjBL model using edmodo in the learning process is effective enough to improve student learning outcomes. Based on the results of the normality test, a significance value of $0.703>0.05$ was obtained. This means that the score data is normally distributed. Graphs of student's pretest and posttest scores in class using the PjBL model and the Edmodo application can be seen in the Figure 1:

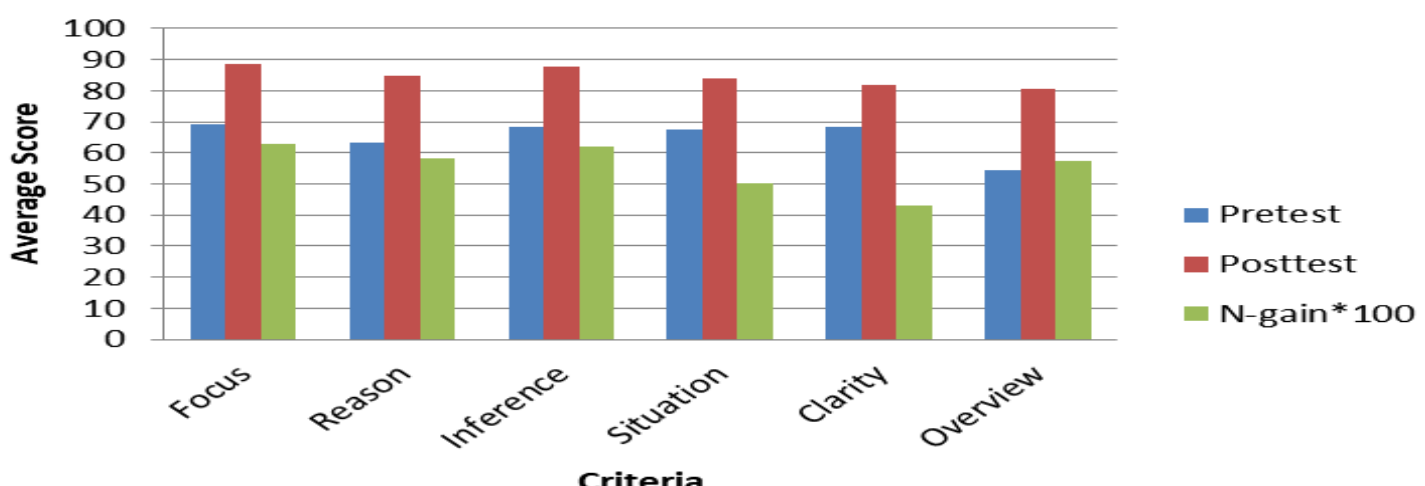

Figure 1. Graph of student's critical thinking skills from several indicators.

Several studies on PjBL show that PjBL can have a positive effect on learning and increase student motivation, emphasizing a student-centered and experiential approach to comprehensive learning. Student's critical thinking skills improve in completing given project assignments and are able to help students to develop collaborative skills (Dole, et.al. 2017). Activities in learning through problems that are packaged in the form of project work also provide an interesting learning experience, have a significant effect on the achievement of learning outcomes and are able to improve student's thinking skills in solving problems (Rahmazatullaili, et al. 2017; Rahardjanto, et al. 2019). In 
integrated science learning, the PjBL strategy is able to improve learning outcomes, understanding and applying the concept of developing integrated science learning media (Safaruddin, et al. 2020; Safaruddin, Ibrahim, et al., 2020). Problem-based learning is able to improve student's thinking skills (Handayani, D., Alperi, M., 2021).

the implementation in the field, students are divided into 7 groups. Then each group designed a different project task. The project that made is to make articles based on literature studies of journals obtained at least the literature used in the last 3 years. Each group looks for the latest journals related to the latest educational issues. From the results of the student groups, the topics of each article project were obtained as follows: (1). STEM, (2). Cooperative Learning Model (3). Audio visual media, (4). Google classroom, (5). Zoom cloud meeting application, (6). Problem Based Learning, (7). HOTS capabilities. After getting supporting references, in groups of students work on articles as the final product of the Capita Selecta Course project. The draft of the article is checked and its progress is reported to the lecturer in 2 meetings. Then input from the lecturer, revised again by the group. And when the assignment is good, a presentation is made to other student groups. Discuss and provide input on project tasks that have been worked on. Final project assignments are collected into one, and good articles will be processed into journals through OJS. The application of the PjBL model is able to produce a project in the form of a product, namely in the form of a written report, a presentation in the form of a power point, recommendations and a ready-to-publish article.

The learning process besides using the PjBL model is also assisted by the edmodo application. The use of this application begins with the creation of student learning accounts using the official edmodo website, namely www.edmodo.com. The lecturer provides a learning code that will be used by students to enter the Edmodo class. On accounts owned by students, students can comment on discussions or announcements given by the lecturer. Students send group assignments to class groups. Other friends discuss in the forum that has been created. From the discussion, it will be seen which students are active and passive. Edmodo display of the Capita Selecta Course can be seen in Figure 2.

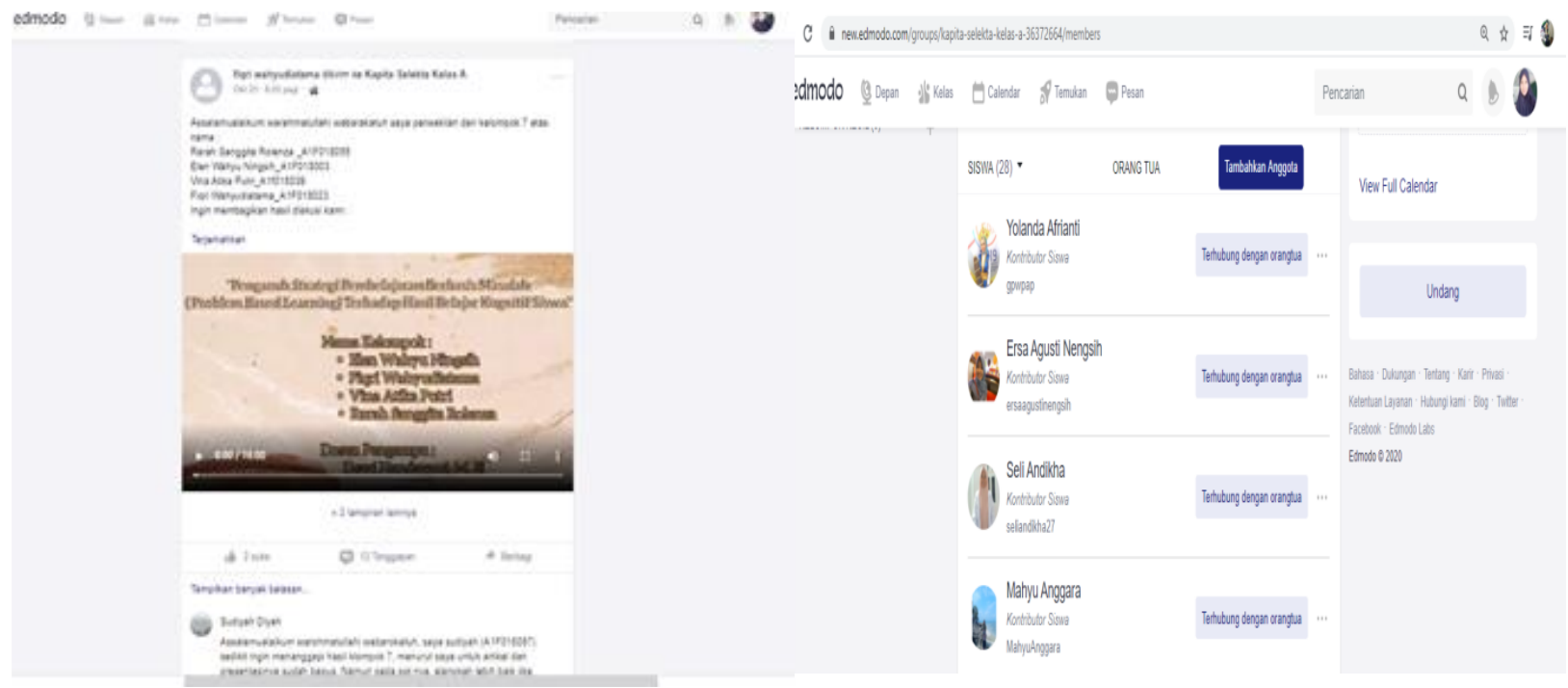

Figure 2. Edmodo class display. 
In learning using the PjBL model, it is carried out through six stages of project-based activities. The scheme for implementing the PjBL model can be seen in Figure 3. Based on Figure 3, it is known that there are 6 stages of the PjBL model, namely providing essential questions, making project planning, compiling a project schedule, monitoring students and project development, assessing or testing results, and evaluating experiences (Lucas in Apriliana, et al. 2018).

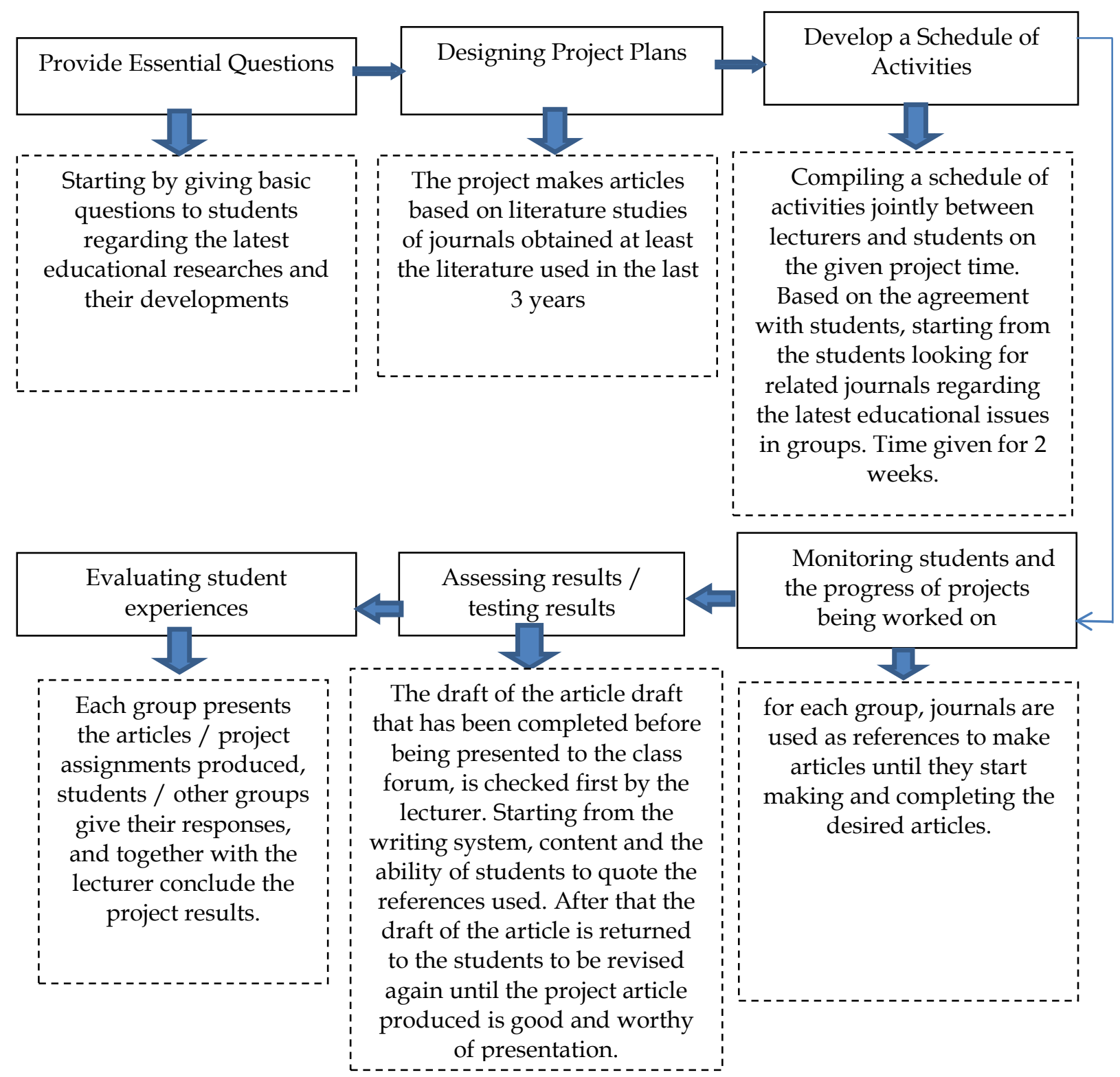

Figure 3. Project-based learning implementation schematic.

Based on interviews conducted directly with students, on average they enjoy learning using this edmodo, here are some interview results quoted from several students:

"Using Edmodo, in my opinion, is very effective as an effort to replace face-to-face learning, although this application cannot replace the full effectiveness of face-to-face learning. In the application, you can send assignments, discuss both groups and individually, you can take quizzes "(Student 3). 
Implementation of Project-Based Learning Model with Edmodo Application in the Capita Selecta Chemistry Course

"Edmodo is an interesting application and can comment, like messages like Facebook. There is a place to collect assignments, then all forums in the class can immediately respond to it so this is very good"(Student 15).

"I think online learning like this is very helpful with the edmodo application, because edmodo has provided a place to collect assignments, such as assignments that we have completed in the form of articles, video presentations, and PPT, so that the collection of assignments is more flexible, then for the implementation of learning more efficiently. because there has been direct notification so that it makes it easier to access and deliver the material it will not be drowned because of the many comments because there is already a separate comment column, indeed the learning process will be more meaningful if it is done face-to-face only now conditions are not possible, but capita learning is selective as well It is as meaningful as face-to-face because it is facilitated by the supporting features of Edmodo, so that the selective capita learning process can be fully understood by students. So I conclude that the selective capita learning process using the Edmodo application is very effective and efficient so that it helps students understand the explanation about making good and correct articles "(Student 27).

The edmodo application has many features that can be used for the implementation of learning. These features can be used and developed by the teacher based on the needs of each teacher and student who has different characteristics. Edmodo is increasingly being used in learning because it can help lecturers to share learning materials and communicate more effectively, poll, assign assignments, share ideas and save time (Ryane, I., \& El Faddouli, NE 2020; Al-Said, KM, 2015; Ompusunggu, VDK, \& Sari, N., 2019). The edmodo application is currently becoming popular because it is able to strengthen the role of teachers, students and connect directly with parents so that the learning process becomes better and controlled (Sumardi, S., \& Muamaroh, M., 2020).

Edmodo features include: 1) Groups, which are used by lecturers to create classes in Edmodo. The class made in edmodo is the Capita Selekta Class. Students can be added by the lecturer to the class that has been made, that is also possible students join directly to the class using class code. 2) Note, is a feature that functions to take notes and can be sent in the form of word, pdf and other files. 3) Alert, a feature whose purpose is the same as notes, but cannot be attached files. 4) Assignment, a feature used to assign assignments to students, both in the form of short questions and descriptions. 5) Quiz, is a feature to provide weekly quizzes or final exams, which can be written directly or sent as a file. 6) Polling, whose function is to poll students on course material or other important matters. 7) Library, used to store all the documents needed and can be directly connected to Google Drive. 8) Progress, serves to see the development of student learning. 9) Edmodo Planner, its function is to record the agenda of scheduled activities/ projects.

Below is a summary of the advantages and disadvantages of the Edmodo application, based on the results of the research that has been done :

Table 4. Strengths and weaknesses of the Edmodo application.

\begin{tabular}{l}
\hline \multicolumn{1}{c}{ Edmodo application } \\
\hline Strengths \\
\hline $\begin{array}{l}\text { The student assignments, a deadline for assignment can be arranged. } \\
\text { upload their assignments }\end{array}$ \\
Student assignments in the form of word / pdf files, photos, videos can be sent without \\
memory limitations
\end{tabular}


Implementation of Project-Based Learning Model with Edmodo Application in the Capita Selecta Chemistry Course

lecturers can comment on assignments performed by students individually / in groups in the comments column, which can be in the form of input, reinforcement, and other communication.

Assessment of assignments collected by students can be directly given by the lecturer.

Applications can be opened using a laptop, it can also be via Android / HP

\section{Weaknesses}

Not all students know the edmodo application, and some have difficulty using the features in it.

There is no video conference yet. So there is no direct interaction between lecturers and students.

In research conducted by Aulia, et al (2019), one of the advantages of Edmodo is that this application can be accessed via a smartphone, so it can be more flexible in learning activities. In this study, the students' responses to the use of the Edmodo application in learning were also seen in Table 5.

Table 5. Percentage of student responses to the edmodo application

\begin{tabular}{lc}
\hline \multicolumn{1}{c}{ Information } & Perscentage (\%) \\
\hline $\begin{array}{l}\text { I like to learn capita selectivity by using an online learning } \\
\text { system like edmodo rather than learning directly / face-to- } \\
\text { face with lecturers. }\end{array}$ & 48,28 \\
\hline $\begin{array}{l}\text { Edmodo is an interesting application in selective capita } \\
\text { learning and its features are complete }\end{array}$ & 89,66 \\
\hline $\begin{array}{l}\text { Edmodo makes me more responsible and disciplined in } \\
\text { collecting assignments. }\end{array}$ & 93,10 \\
\hline $\begin{array}{l}\text { Edmodo gave me new experiences / nuances in capita } \\
\text { selecta learning }\end{array}$ & 96,55 \\
\hline Assignment through edmodo is fast and practical & 89,66 \\
\hline $\begin{array}{l}\text { Edmodo application makes it easier for me to access lecture } \\
\text { materials and project assignments that are presented per } \\
\text { group. }\end{array}$ & 93,10 \\
\hline $\begin{array}{l}\text { I can improve my understanding of the development of } \\
\text { Capita selecta through learning videos / group presentations } \\
\text { uploaded through edmodo }\end{array}$ & 86,21 \\
\hline $\begin{array}{l}\text { I prefer to collect assignments by uploading videos / } \\
\text { presentations on edmodo rather than appearing directly in } \\
\text { class during lectures face to face with lecturers }\end{array}$ & 58,62 \\
\hline
\end{tabular}

Questionnaire modified from research by Agustiani, et al. (2019).

From Table 5 above, students prefer face-to-face learning rather than using the Edmodo application. Only $48.28 \%$ of students like learning through the edmodo application. This is because so far students learn face-to-face. So students are not familiar with online learning patterns. In the current pandemic era, Edmodo is very helpful in the learning process because it makes students more active, independent and responsible for their duties. As many as $96.55 \%$ of students think that the Edmodo application provides new nuances in capita selecta lectures. Because this is the first time they use it in learning. As many as $93.10 \%$ of students also became more 
Implementation of Project-Based Learning Model with Edmodo Application in the Capita Selecta Chemistry Course

responsible, disciplined in collecting assignments and students found it easier to access lecture materials.

\section{CONCLUSIONS}

Based on the research conducted, it can be concluded that there is an increase in student learning outcomes scores from 65.172 (pre-test average score) to 84.586 (average posttest score) with an N-Gain score of 0.557 which is included in the moderate category. This shows that there has been a significant increase in student learning outcomes using the PjBL model and the edmodo application. The results of the student response questionnaire to the learning used were very positive. As many as $96.55 \%$ of students think that the Edmodo application provides new nuances in selective capita lectures. Students also become more responsible, disciplined in collecting assignments and students find it easier to access lecture material. Therefore, Project Based Learning (PjBL) learning model using the Edmodo application can be recommended to be applied by the lecture. In learning it would be better if digital-based learning media were added.

\section{REFERENCES}

Alacapinar, F. (2008). Effectiveness of project-based learning. Eurasian Journal of Educational Research (EJER), 8 (33), 17-34.

Al-Said, K. M. (2015). Students' perceptions of edmodo and mobile learning and their real barriers towards them. Turkish Online Journal of Educational Technology, 14(2), 167-180.

Almes Gangga. (2013). Penerapan model project based learning dalam meningkatkan motivasi dan hasil belajar. Skripsi Universitas Negeri Padang Tidak diterbitkan.

Amrullah, A. K., Ibrahim, M., \& Widodo, W. (2017). Implementasi pembelajaran berbasis masalah untuk melatihkan kemampuan berpikir kreatif dan penguasaan konsep siswa kelas V sekolah dasar. Jurnal Review Pendidikan Dasar : Jurnal Kajian Pendidikan dan Hasil Penelitian, 3(1), 378-387. http://dx.doi.org/10.26740/jrpd.v3n1.p378-387.

Apriliana, M. R., Ridwan, A., Hadinugrahaningsih, T., \& Rahmawati, Y. (2018). Pengembangan soft skills peserta didik melalui integrasi pendekatan science, technology, engineering, arts, and mathematics (STEAM) dalam pembelajaran asam basa. JRPK: Jurnal Riset Pendidikan Kimia, 8(2), 101 - 110. https://doi.org/10.21009/JRPK.082.05.

Arikunto, S. (2013). Prosedur penelitian suatu pendekatan praktik. Jakarta: PT. Rineka Cipta.

Aulia, L. N., Susilo, S., \& Subali, B. (2019). Upaya peningkatan kemandirian belajar siswa dengan model problem-based learning berbantuan media Edmodo. Jurnal Inovasi Pendidikan IPA, 5(1), 69-78. https:// doi.org/10.21831/jipi.v5i1.18707

Devy Alvionita, Prabowo, \& Z.A. Imam Supardi. (2020). Problem based learning with the sets method to improve the student's critical thinking skill of senior high school. IJORER : International Journal of Recent Educational Research, 1(3), 246-260. https://doi.org/10.46245/ijorer.v1i3.46.

Dole, S. , Bloom, L. , \& Doss, K. K. (2017). Engaged learning: impact of PBL and PjBL with elementary and middle grade students. Interdisciplinary Journal of Problem-Based Learning, 11(2). https:// doi.org/10.7771/1541-5015.1685.

Facione, P. A. (2011). Think critically. Englewood Cliffs, NJ: Pearson.

Ghufroni, G., Kurniawan, P. Y., Yono, R. R., \& Hakim, M. W. A. (2020). Keefektifan penggunaan buku ajar mata kuliah apresiasi dan kajian drama berbasis kebudayaan Brebes. Jurnal Ilmiah Semantika, 2(01). https:// doi.org/10.46772/semantika.v2i01.262. 
Implementation of Project-Based Learning Model with Edmodo Application in the Capita Selecta Chemistry Course

Handayani, D., Sundaryono, A., \& Rohiat, S. (2019). Think pair share cooperative learning model using edmodo application. Proceedings of the 3rd Asian Education Symposium (AES 2018). https:// doi.org/10.2991/aes-18.2019.60.

Handayani, D., Alperi, M. (2021). Problem solving model using video application. Journal of Physics: Conference Series, 1731. doi:10.1088/1742-6596/1731/1/012024

Hake, R. (1999). Analyzing Change/Gain Score. Indiana: Indiana University.

Ihsan, M. S., Ramdani, A., \& Hadisaputra, S. (2019). Pengembangan E-Learning pada pembelajaran kimia untuk meningkatkan kemampuan berpikir kritis peserta didik. Jurnal Pijar MIPA, 14(2). http://dx.doi.org/10.29303/jpm.v14i2.1238.

Jang, H. (2016). Identifying 21st Century STEM competencies using workplace data. Journal of Science Education and Technology, 25(2), 284-301. https://doi.org/10.1007/s10956-0159593-1.

Kadir. (2016). Statistika terapan: Konsep, contoh, dan analisis data dengan program SPSS/Lisrel dalam penelitian edisi kedua. Jakarta: Rajawali Pers.

Agustiani, M., Ningsih, S., \& Muris, A. A. (2019). Respon mahasiswa terhadap pembelajaran bahasa inggris berbasis blended learning melalui edmodo di universitas Baturaja. PEDAGOGIA, 17(2), 108-119. https://doi.org/10.17509/pdgia.v17i2.18528.

Mergendoller, J. R., Maxwell, N. L., \& Bellisimo, Y. (2006). The effectiveness of problem-based instruction: A comparative study of instructional methods and student characteristics. Interdisciplinary Journal of Problem-Based Learning, 1(2), 49-69. https://doi.org/10.7771/1541-5015.1026

Mioduser, D., \& Betzer, N. (2008). The contribution of project-based-learning to high-achievers' acquisition of technological knowledge and skills. International Journal of Technology and Design Education, 18(1), 59-77. https://doi.org/10.1007/s10798-006-9010-4.

Ompusunggu, V. D. K., \& Sari, N. (2019). Efektifitas penggunaan e-learning berbasis edmodo terhadap kemampuan komunikasi matematika. Jurnal Curere, 3(2). https://doi.org/10.36764/jc.v3i2.250.

Putranti, N. (2013). Cara membuat media pembelajaran online menggunakan Edmodo. Jurnal $\begin{array}{llll}\text { Pendidikan Informatika Dan 139-147. } & \text { Sains, 2(2), }\end{array}$ https://journal.ikippgriptk.ac.id/index.php/saintek/article/view/224/223.

Purwati, Ratna., Hobri., \& Arif Fatahillah. (2016). Analisis kemampuan berfikir kritis siswa dalam menyelesaikan masalah persamaan kuadrat pada pembelajaran model creative problem solving. Jurnal Kadikma, 7(1), 84-93.

Rahardjanto, A., Husamah, \& Fauzi, A. (2019). Hybrid-PjBL: Learning outcomes, creative thinking skills, and learning motivation of preservice teacher. International Journal of Instruction, 12(2), 179-192. https:// doi.org/10.29333/iji.2019.12212a

Rahman, MK, Suharto, B, Iriani, R. (2019). Meningkatkan berpikir kreatif dan hasil belajar menggunakan model Pjbl berbasis STEAM pada materi larutan elektrolit dan nonelektrolit. Journal of Chemistry And Education, 3(1), 10-22.

Rahmazatullaili, R., Zubainur, C. M., \& Munzir, S. (2017). Kemampuan berpikir kreatif dan pemecahan masalah siswa melalui penerapan model project based learning. Beta Jurnal Tadris Matematika, 10(2), 166-183. https:// doi.org/10.20414/ betajtm.v10i2.104

Ryane, I., \& El Faddouli, N. E. (2020). A case study of using edmodo to enhance computer science learning for engineering students. International Journal of Emerging Technologies in Learning, 15(3), 62-73. https://doi.org/10.3991/ijet.v15i03.11252

Safaruddin, Degeng, I. N. S., Setyosari, P., \& Murtadho, N. (2020). The effect of PJBL with WBL media and cognitive style on students' understanding and science-integrated concept application. Jurnal Pendidikan IPA Indonesia, 9(3), 384-395. https://doi.org/10.15294/jpii.v9i3.24628

Safaruddin, S., Ibrahim, N., Juhaeni, J., Harmilawati, H., \& Qadrianti, L. (2020). The Effect of Project-Based Learning Assisted by Electronic Media on Learning Motivation and Science 
Implementation of Project-Based Learning Model with Edmodo Application in the Capita Selecta Chemistry Course

Process Skills. Journal of Innovation in Educational and Cultural Research, 1(1), 22-29. https://doi.org/10.46843/jiecr.v1i1.5

Safitri, A., Aribowo, D., \& Fatkhurrokhman, M. (2020). Analisa perbandingan model PJBL dengan model TCL menggunakan PLC ZELIO pada instalasi motor listrik kelas XII di SMK VOCTECH 1 Kota Tangerang. EDUTEC: Journal of Education And Technology, 3(2), 137-150. https:// doi.org/10.29062/edu.v3i2.41.

Scriven, M., \& Paul, R. (1996). Defining critical thinking: A draft statement for the National Council for Excellence in Critical Thinking. http://www.criticalthinking.org/University/univlibrary/library.nclk.

Prasetiyono, S \& Sondang, M. (2014). Pengembangan media pembelajaran E-Learning berbasis edmodo pada kompetensi dasar menerapkan konsep dasar sistem komunikasi data sinyal digital melalui media kabel fiber dan frekuensi radio Di SMK Negeri 1 Jetis Mojokerto. Journal Pendidikan Teknik Elektro, 3(2), 151-156.

Sugiyono. (2010). Metode penelitian pendidikan pendekatan kuantitatif, kualitatif, dan RED. Bandung: Alfabeta.

Sumardi, S., \& Muamaroh, M. (2020). Edmodo impacts: Mediating digital class and assessment in english language teaching. Cakrawala Pendidikan, 39(2), 319-331. https://doi.org/10.21831/cp.v39i2.30065.

Syofiarni, Y. (2014). Edmodo. Makalah AKADEMI KOMUNITAS Negeri Padang Pariaman.

Zakaria M. (2020). Tentang edmodo: Pengertian, manfaat, dan Fitur-Fiturnya yang wajib anda ketahui. Nesabamedia. https://www.nesabamedia.com/pengertian-manfaat-dan-fituredmodo.

\section{*Dewi Handayani (Corresponding Author)}

Chemistry Education Study Program, Universitas Bengkulu

WR Supratman St, Kandang Limun. Bengkulu, 38123, Indonesia

Email: $\underline{\text { d.handayani@unib.ac.id }}$

\section{Endang Widi Winarni}

Department of Elementary Education, Education Faculty, University of Bengkulu

WR Supratman St, Kandang Limun. Bengkulu, 38123, Indonesia

Email: endangwidi@unib.ac.id

\section{Agus Sundaryono}

Graduate School of Science Education, Universitas Bengkulu, WR Supratman St, Kandang Limun. Bengkulu, 38123, Indonesia

Email: asundaryono@unib.ac.id

\section{Lutfi Firdaus}

Graduate School of Science Education, Universitas Bengkulu, WR Supratman St, Kandang Limun. Bengkulu, 38123, Indonesia

Email: lutfi@unib.ac.id 